\title{
Inherited Creutzfeldt-Jakob disease
}

INSERM

\section{Source}

INSERM. (1999). Orphanet: an online rare disease and orphan drug data base. Inherited Creutzfeldt-Jakob disease. ORPHA:282166

Inherited or familial Creutzfeldt-Jakob disease (fCJD) is a very rare form of genetic prion disease (see this term) characterized by typical CJD features (rapidly progressive dementia, personality/behavioral changes, psychiatric disorders, myoclonus, and ataxia) with a genetic cause and sometimes a family history of dementia. 